\title{
Customers' Attitude towards Shopping at Home
}

\section{G. Thamaraiselvi}

\begin{abstract}
Traditional marketing, sellers meet the difficulty to reach a wide of customers in world wide. Now it was changed, there is an easy way to reach the customer is internet. Both buyers and sellers from world meet together and exchange their products at minimum of amount. It is an ease way of marketing. The aim of this study is to study customers' preference towards online websites and also preferred products to shop online and also to identify the satisfaction level of customers towards online shopping. In case of eatables, people don't want to take risk regarding their health. Likewise, they don't have much interest to buy vegetables from online compared with offline shopping. This is due to lack of bargaining of price. Most of the online shoppers dissatisfied with the privacy of data due to some recent issues. These are lessons to the online service providers to create awareness among people about their business. It helps to motivate them to buy from their websites. Moreover, people also should more conscious while shopping.
\end{abstract}

Key Words: Online Marketing, Online Shopping, Electronic Marketing, Customers'Satisfaction, Online Websites

\section{INTRODUCTION}

Internet marketing is like digging a gold mine. $97 \%$ people focus on $99 \%$ dirt and keep complaining. $3 \%$ people focus on $1 \%$ gold and keep it collecting.

- Sanja Budin, Owner, smartbizprofits.com

The economy of all country depends upon marketing. Marketing is nothing but buyer and seller meet together for exchange of goods at minimum amount of cost. Marketing helps seller to earn profit by identifying their buyers. It also helps to meet the potential customer. At the same time, traditional marketing we cannot measure number of persons who read sellers' advertisement and how many of them took favorable decision to buy a product. In case of buyer, availability of brand is very narrow. Traditional marketing, sellers meet the difficulty to reach a wide of customers in world wide. Now it was changed, there is an easy way to reach the customer is internet. Both buyers and sellers from world meet together and exchange their products at minimum of amount. It is an ease way of marketing. The buyer can access variety of goods from various sellers from all over the world. They are having variety of choice to select. Internet marketing is also helps the seller to advertise their products with a minimum of cost. Electronic marketing is nothing but seller display their products through internet and buyer make an order to buy a product by using internet. It helps to save time and energy.

\subsection{Features of Electronic Marketing}

Electronic marketing became popular only because its nature. The following are the nature or characteristics of electronic marketing;

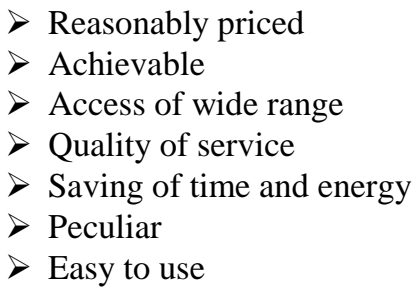

\subsection{Elements of Electronic Marketing}

Electronic marketing has various elements as listed below;

$$
\begin{aligned}
& \text { - Affiliate Marketing } \\
& \text { - Blog } \\
& \text { - Banner } \\
& \text { - Social Network } \\
& \text { - Forum } \\
& \text { - Email } \\
& \text { - Analytics }
\end{aligned}
$$

\subsection{Benefits of Electronic marketing}

The following are some benefits acquired by the business as well as buyer through electronic marketing

oCompared with other marketing channels it has lowest cost

o It helps to reach wide range of customers in world wide oIt is an easy way to earn more profits

oIt is easy to measure

oIt helps buyer to access global competitive products oIt helps buyer to access wide range of products

$\circ$ It helps buyer to avail certain offers and discount

\section{REVIEW OF LITERATURE}

Kaur, Pathak and Kaur (2015) stepped to identify the electronic marketing at global scenario. They found that the respondents don't have much knowledge of online shopping. Because of lack of awareness many of them are not using these to buy products. They concluded that electronic marketing is an easy way to reach customers. Quality service can be offered by giving personal attention by market to customer. Eid (2014) identified the factors which are influencing the customers' satisfaction, trust and loyalty in Saudi Arabia. He found that user interface quality and quality of electronic commerce websites are the major factors which influence the customers' satisfaction. He concluded that the customer attitude towards electronic commerce in the developing country of Saudi Arabia is totally different from other countries like German and China consumers. 


\section{THE SCOPE OF THE STUDY}

This study covered to Dindigul town. The major scope is to study the customers' preference towards online websites, preferred products to shop online, customers' reference towards online websites and also their satisfaction level towards online shopping.

\section{OBJECTIVES OF THE STUDY}

The following are the objectives of the present study:

i) To study customers' preference towards online websites and also preferred products to shop online

ii) To identify the satisfaction level of customers towards online shopping

\section{RESEARCH METHODOLOGY}

This study has been carried out on shopping at home that is online shopping. Data used in this study collected basically from the Primary data. Primary data collected through personal interview method conducting the persons who are supposed to have knowledge about the topic. Secondary data also collected from various sources including websites, newspapers, various published and unpublished article about the usage and satisfaction level of respondents

\section{DATA INTERPRETATION}

This study has been carried out on customers' satisfaction towards shop at home. Questionnaire entails the questions are related to level of usage of online websites, products preferred to buy from online and customers' satisfaction level towards their shopping In questionnaire consists the options are frequently using, rarely using and never used and also Highly Satisfied, Satisfied, Neutral, Dissatisfied and Highly Dissatisfied.

Table 6.1

Demographic Profile of Respondents (No. of Respondents 200)

\begin{tabular}{|c|c|c|c|}
\hline \multicolumn{2}{|c|}{ Demographic Factors } & $\begin{array}{l}\text { No. of } \\
\text { Respondents }\end{array}$ & $\begin{array}{l}\text { Percentage } \\
(\%)\end{array}$ \\
\hline \multirow{3}{*}{ Gender } & Male & 112 & 56 \\
\hline & Female & 88 & 44 \\
\hline & Total & 200 & 100 \\
\hline \multirow{4}{*}{ Age(Years) } & Below 30 & 68 & 34 \\
\hline & $31-40$ & 72 & 36 \\
\hline & $41-50$ & 54 & 27 \\
\hline & Above 50 & 6 & 3 \\
\hline & Total & 200 & 100 \\
\hline \multirow[t]{3}{*}{ Marital Status } & Single & 96 & 48 \\
\hline & Married & 104 & 52 \\
\hline & Total & 200 & 100 \\
\hline \multirow{5}{*}{$\begin{array}{l}\text { Educational } \\
\text { Qualifications }\end{array}$} & Illiterate & 22 & 11 \\
\hline & Up to HSC & 60 & 30 \\
\hline & Graduate & 114 & 57 \\
\hline & Professional & 4 & 2 \\
\hline & Total & 200 & 100 \\
\hline \multirow{4}{*}{ Occupation } & Employed & 180 & 90 \\
\hline & Business & 16 & 8 \\
\hline & Retired & 4 & 2 \\
\hline & Total & 200 & 100 \\
\hline
\end{tabular}

The above table explained that the demographic profile of 200 respondents. Among 200 respondents, 112 $(56 \%)$ are male respondents and remaining $88(44 \%)$ are female respondents. Maximum of respondents are belong to the age category of 31 to 40 that is $72(36 \%)$. Only $6(3 \%)$ respondents are belong to the category of above 50 years. Most of the respondents $104(52 \%)$ are married in status. Other respondents $96(48 \%)$ are single in status. Most of the respondents $114(57 \%)$ completed their graduation. This study covered only $4(2 \%)$ professionals as respondents. There are $22(11 \%)$ are not even completed their school education. Though they are not completed their primary education, they are accessing online for make a shopping by the help of their blood relation/ relatives/ spouse. Most of the respondents $180(90 \%)$ are working as an employee in various companies at various positions. Only $16(8 \%)$ respondents are doing their business.

\section{Table 6.2}

Customers' preference towards the choice of shopping (No. of Respondents 200)

\begin{tabular}{|l|l|l|l|l|l|}
\hline $\begin{array}{l}\text { S.N } \\
\text { o }\end{array}$ & $\begin{array}{l}\text { Name of the } \\
\text { Product }\end{array}$ & $\begin{array}{l}\text { Frequentl } \\
\mathbf{y}\end{array}$ & $\begin{array}{l}\text { Occasion } \\
\text { ally }\end{array}$ & $\begin{array}{l}\text { Rar } \\
\text { ely }\end{array}$ & $\begin{array}{l}\text { Nev } \\
\text { er }\end{array}$ \\
\hline 1 & Jewellery & 30 & 10 & 140 & 20 \\
\hline 2 & Textiles & 135 & 15 & 20 & 30 \\
\hline 3 & Gift articles & 15 & 10 & 115 & 60 \\
\hline 4 & Books/CD's & 40 & 35 & 110 & 15 \\
\hline 5 & $\begin{array}{l}\text { Electronic } \\
\text { products }\end{array}$ & 10 & 5 & 15 & 170 \\
\hline 6 & $\begin{array}{l}\text { Beauty and } \\
\text { Health } \\
\text { products }\end{array}$ & 43 & 25 & 53 & 79 \\
\hline 7 & Grocery & 10 & 5 & 1 & 184 \\
\hline 8 & $\begin{array}{l}\text { Baby } \\
\text { products }\end{array}$ & 68 & 57 & 67 & 8 \\
\hline 9 & $\begin{array}{l}\text { Mobile and } \\
\text { Laptop }\end{array}$ & 15 & 26 & 69 & 90 \\
\hline 10 & $\begin{array}{l}\text { Sports and } \\
\text { Fitness } \\
\text { Products }\end{array}$ & 5 & 15 & 18 & 162 \\
\hline 11 & $\begin{array}{l}\text { Eatables(Fo } \\
\text { od items) }\end{array}$ & 10 & 5 & 1 & 184 \\
\hline
\end{tabular}

The above table shows that customers' preference towards the products which they want to buy in online. Maximum of respondents $135(667.5 \%)$ prefer to buy clothes from online frequently. Some of the respondents $140(70 \%)$ prefer to buy imitation jewellery from online sellers very rarely. Only 150 (75\%) respondents are interested to purchase gift articles rarely from online websites. The respondents those who are willing to read books which are not available offline, they only $110(55 \%)$ prefer to buy books/CD's from online. Most of the respondents $170(85 \%)$ are not willing to buy electronic products like fridge, washing machine, etc. from online.

This is because of lack of confident about after sales service. Most of the female and male respondents 79 (39.5\%) are not willing to buy products which are relating to beauty and health. Even grocery items are available from various online websites, $184(92 \%)$ respondents are not prefer online to buy. The respondents $68(34 \%)$ are very eagerly access online websites particularly which are offering baby products. At the same time, 90 (45\%) respondents are not willing to buy mobiles and laptops from online. Even though maximum of respondents are not interested to buy mobiles and laptops, remaining $69(34.5 \%)$ are rarely buying these products from online. Likewise, $162(81 \%)$ respondents are not willing to buy sports and fitness products. Only $18(9 \%)$ respondents are 
buying these products rarely. Now, online shopping is even easy to order eatables, maximum of respondents $184(92 \%)$ are stay back from online shopping.

\section{Findings}

It is found from the above interpretation that most of the online shoppers buy clothes from online frequently. Apart from clothing, they also prefer to buy gift articles, imitation jewellery and books/CD. It explains that they are willing to buy online products only after verifying the features like colour, flavour, design and so on. In case of beauty and health products, online shoppers prefer off line shopping due to health conscious. And also they don't want to buy electronic products like washing machine, fridge, etc. which are require after sales service. Most of the online shoppers are preferring to bargain, so they don't want to shop products which are available near home like grocery and vegetables.

Table 6.3

Customers' preference towards online shopping websites (No. of Respondents 200)

\begin{tabular}{|c|c|c|c|c|c|}
\hline $\begin{array}{c}\text { S. } \\
\text { No. }\end{array}$ & Websites & $\begin{array}{c}\text { Frequentl } \\
\mathbf{y}\end{array}$ & $\begin{array}{c}\text { Occasionall } \\
\mathbf{y}\end{array}$ & $\begin{array}{c}\text { Rarel } \\
\mathbf{y}\end{array}$ & Never \\
\hline 1 & Amazon & 30 & 10 & 140 & 20 \\
\hline 2 & Flipkart & 135 & 15 & 20 & 30 \\
\hline 3 & Jabong & 15 & 10 & 115 & 60 \\
\hline 4 & Ebay & 40 & 35 & 110 & 15 \\
\hline 5 & Myntra & 10 & 5 & 15 & 170 \\
\hline 6 & Snap deal & 43 & 25 & 53 & 79 \\
\hline 7 & Shop clues & 10 & 5 & 1 & 184 \\
\hline 8 & Junglee & 0 & 0 & 0 & 200 \\
\hline 9 & Tradus & 0 & 0 & 0 & 200 \\
\hline 10 & Yebhi & 0 & 0 & 0 & 200 \\
\hline 11 & Firstcry & 0 & 0 & 0 & 200 \\
\hline 12 & Homeshop18 & 0 & 0 & 0 & 200 \\
\hline 13 & Foodpanda & 10 & 5 & 1 & 184 \\
\hline 14 & Zomato & 0 & 0 & 0 & 200 \\
\hline 15 & Swiggy & 0 & 0 & 0 & 200 \\
\hline 16 & Tastygana & 0 & 0 & 0 & 200 \\
\hline 17 & Justeat & 0 & 0 & 0 & 200 \\
\hline 18 & Pizza Hut & 68 & 57 & 67 & 8 \\
\hline 19 & Bigbasket & 15 & 26 & 69 & 90 \\
\hline 20 & Grofers & 5 & 15 & 18 & 162 \\
\hline 21 & Zopnow & 0 & 0 & 0 & 200 \\
\hline 22 & $\begin{array}{c}\text { Nature's } \\
\text { Basket }\end{array}$ & 0 & 0 & 0 & 200 \\
\hline 23 & $\begin{array}{c}\text { Reliance } \\
\text { Fresh }\end{array}$ & 15 & 10 & 115 & 60 \\
\hline 24 & $\begin{array}{c}\text { Amazon } \\
\text { Pantry }\end{array}$ & 0 & 0 & 0 & 200 \\
\hline 25 & Bazaar Cart & 10 & 5 & 15 & 170 \\
\hline & & & & & \\
\hline
\end{tabular}

The above table express the customers' preference to online shopping websites which are providing various categories of products to fulfil the demand of the consumers. Even though there are many websites offer products, only 25 online shopping websites were asked from the respondents. Among them there are $12 \mathrm{c}$ websites such as jungle, tradus, yebhi, firstcry, homeshop18, zomanto, swiggy, tastygana, justeat, zopnow, mature's basket, amazon pantry are never used by the respondents. Among remaining websites maximum of the respondents $140(70 \%)$ are rarely using to buy the products. Most of the respondents 135 (67.5\%) are prefer to buy products from flipkart frequently. Maximum of respondents $115(57.5 \%)$ are using jabong to buy products rarely. Most of the respondents $170(85 \%)$ are answered as they are never used myntra for shopping. Likewise, 184 $(92 \%)$ respondents also not interested to use shopclues to buy.

Though maximum of respondents 184 (92\%) are never using foodpanda to order eatables, some of the respondents still prefer to order eatables from foodpanda. Among other eatables shopping websites, maximum of the respondents prefer to order from pizzahurt. In case of vegetables, only miner amount of respondents prefer to purchase vegetables from bigbasket. $115(57.5 \%)$ respondents are prefer reliance fresh to order vegetables. In case of bazaar cart 170 (85\%) respondents are never using this to buy products.

\section{Findings}

It is observed from the above result and interpretation that most of the online shoppers are preferring online websites which are available for buying textiles, imitation jewellery, electrical products, gifts articles and even books/CD. At the same time, very fewer online shoppers prefer the websites which are offering vegetables, grocery and eatables. This is because of lack of awareness and an important thing is lack of trust on that particular websites.

Table 6.4

Customers' attitude towards online shopping (No. of Respondents $=200$ )

\begin{tabular}{|c|c|c|c|c|c|c|}
\hline S.No. & Statements & HS & $\mathrm{S}$ & $\mathrm{N}$ & DS & HDS \\
\hline 1 & Secured purchase & $\begin{array}{c}12 \\
0\end{array}$ & 55 & $\begin{array}{l}1 \\
0\end{array}$ & 12 & 3 \\
\hline 2 & It is easy to use & $\begin{array}{c}13 \\
5\end{array}$ & 40 & 6 & 12 & 7 \\
\hline 3 & It helps to save time & $\begin{array}{c}15 \\
2\end{array}$ & 33 & 4 & 6 & 5 \\
\hline 4 & $\begin{array}{c}\text { It is a speedy process to buy a } \\
\text { product }\end{array}$ & $\begin{array}{c}13 \\
6\end{array}$ & 24 & 3 & 17 & 20 \\
\hline 5 & It is reliable & $\begin{array}{c}15 \\
8\end{array}$ & 18 & 7 & 12 & 5 \\
\hline 6 & $\begin{array}{l}\text { Deals and discounts offered by } \\
\text { the company is benefit }\end{array}$ & 96 & 18 & $\begin{array}{l}1 \\
4\end{array}$ & 63 & 9 \\
\hline 7 & $\begin{array}{l}\text { Gathering information about } \\
\text { products is easy }\end{array}$ & $\begin{array}{c}11 \\
5\end{array}$ & 23 & $\begin{array}{l}1 \\
9\end{array}$ & 27 & 16 \\
\hline 8 & There is a wide range of choice & $\begin{array}{c}10 \\
7\end{array}$ & 36 & $\begin{array}{l}1 \\
7\end{array}$ & 18 & 22 \\
\hline 9 & $\begin{array}{l}\text { There is an easy payment } \\
\text { mechanism }\end{array}$ & 59 & 67 & $\begin{array}{l}1 \\
8\end{array}$ & 47 & 9 \\
\hline 10 & $\begin{array}{l}\text { There is a quick delivery of } \\
\text { products and services }\end{array}$ & 63 & 78 & $\begin{array}{l}1 \\
3\end{array}$ & 31 & 15 \\
\hline 11 & $\begin{array}{l}\text { It helps to access global } \\
\text { marketing }\end{array}$ & $\begin{array}{c}11 \\
8\end{array}$ & 26 & $\begin{array}{l}1 \\
1\end{array}$ & 23 & 22 \\
\hline 12 & $\begin{array}{l}\text { The quality of products meet } \\
\text { my expectations }\end{array}$ & $\begin{array}{c}12 \\
2\end{array}$ & 15 & $\begin{array}{l}1 \\
7\end{array}$ & 40 & 6 \\
\hline 13 & $\begin{array}{l}\text { It helps to access latest } \\
\text { products }\end{array}$ & 76 & 59 & $\begin{array}{l}1 \\
6 \\
\end{array}$ & 39 & 10 \\
\hline 14 & It is easy to access anytime & $\begin{array}{c}11 \\
3\end{array}$ & 77 & 3 & 3 & 4 \\
\hline 15 & $\begin{array}{l}\text { There is a possibility to } \\
\text { cancellation of ordered } \\
\text { products }\end{array}$ & $\begin{array}{c}15 \\
4\end{array}$ & 5 & 3 & 35 & 3 \\
\hline 16 & $\begin{array}{l}\text { The procedures to order } \\
\text { products is simple }\end{array}$ & 88 & 23 & $\begin{array}{l}2 \\
1\end{array}$ & 54 & 14 \\
\hline 17 & $\begin{array}{l}\text { The information provided in } \\
\text { the website is useful }\end{array}$ & $\begin{array}{c}11 \\
4\end{array}$ & 65 & 5 & 11 & 5 \\
\hline 18 & $\begin{array}{c}\text { There is an easy process for } \\
\text { making payment }\end{array}$ & $\begin{array}{c}13 \\
5\end{array}$ & 23 & 9 & 27 & 6 \\
\hline 19 & There is a privacy of data & 43 & 14 & 8 & $\begin{array}{c}11 \\
5\end{array}$ & 20 \\
\hline 20 & Return policy is simple & 23 & $\begin{array}{c}11 \\
5\end{array}$ & $\begin{array}{l}1 \\
5\end{array}$ & 38 & 9 \\
\hline 21 & $\begin{array}{l}\text { They charged lower amount for } \\
\text { shipping }\end{array}$ & 5 & 4 & 2 & 73 & 116 \\
\hline 22 & Complaints handling is good & 38 & 49 & $\begin{array}{l}2 \\
8\end{array}$ & 41 & 44 \\
\hline
\end{tabular}




\begin{tabular}{|c|c|c|c|c|c|c|}
\hline 23 & The quality of packing is good & $\begin{array}{c}11 \\
6\end{array}$ & 73 & 3 & 5 & 3 \\
\hline 24 & $\begin{array}{c}\text { It is easy to replace the } \\
\text { defective products }\end{array}$ & 98 & 41 & $\begin{array}{c}1 \\
6\end{array}$ & 38 & 7 \\
\hline 25 & Refund policy is good & 78 & 47 & $\begin{array}{c}1 \\
2\end{array}$ & 53 & 10 \\
\hline 26 & $\begin{array}{c}\text { Recommend my friends and } \\
\text { relatives to buy online }\end{array}$ & $\begin{array}{c}12 \\
9\end{array}$ & 48 & 6 & 13 & 4 \\
\hline
\end{tabular}

Findings

The above table explains that the respondents' satisfaction level by using online websites to buy their desired products. Most of the respondents get satisfaction with the security of purchase that is lack of fear of theft while making physical shopping, it is very easy to make an order for which product they like to buy, of course it helps to save time and also energy, it is very speedy one, they have a trust with online sellers and providers, various discounts and gift vouchers offered by a particular website, brief information provided about the products, there is a wide range of products available for the buyer to select, it provides easy payment methods, delivery of products on time, it helps to reach global sellers, moreover it opens at anytime and access from anywhere, replacing of defective products is good, complaints handling methods, packing of products, refund policy of the seller. Though many numbers of statements get satisfied by the respondents, some of the terms which are still cannot to satisfy the respondents like charge charged for shipping of products and maintain data privacy.

\section{CONCLUSION}

Technology entered into maximum of the fields including commerce. Technology helps both the sellers and buyers to meet together from all over the world in order to fulfil their needs. It helps the consumer to know about the recent development in commerce and also offer new products which are introduced to worldwide people. The conclusion framed based on the findings of this study that most of the respondents prefer to buy products through online shopping. They feel that they get maximum of choice from online compared with offline shopping. Another thing is they can easily buy a product by postponing the payment (cash on delivery). Due to this, the people attract to prefer theseonlineshopping.

Now a day many numbers of websites provide variety of goods at lowest cost. But still many of the respondents prefer only well -known websites like flipkart, amazon, jabong, food panda, pizza hurt, etc. This is because of lack of awareness of other websites. In case of eatables, people don't want to take risk regarding their health. Likewise, they don't have much interest to buy vegetables from online compared with offline shopping. This is due to lack of bargaining of price. Most of the online shoppers dissatisfied with the privacy of data due to some recent issues. These are lessons to the online service providers to create an awareness among people about their business. It helps to motivate them to buy from their websites. Moreover, people also should more conscious while shopping by using strong password, confirm that special offers in service provider website, using well known stores, etc. It is understand from these result that online shopping may provide unique benefits and so on advantages but it will never ever replace the experience of shopping in off line shopping that is from retail stores.

\section{REFERENCE}

1. Kaur, Parminder, and Ashutosh Pathak. "E-marketing-a global perspective." International Journal of Engineering Research and Applications 5.2 (2015): 116-124.

2. Alawneh, Ali, Hasan Al-Refai, and Khaldoun Batiha. "Measuring user satisfaction from e-Government services: Lessons from Jordan." Government Information Quarterly 30.3 (2013): 277-288

3. Eid, Mustafa I. "Determinants of e-commerce customer satisfaction, trust, and loyalty in Saudi Arabia." Journal of electronic commerce research 12.1 (2011): 78.Eid, Mustafa I. "Determinants of e-commerce customer satisfaction, trust, and loyalty in Saudi Arabia." Journal of electronic commerce research 12.1 (2011): 78.

4. Matikiti, Rosemary, Bola Afolabi, and Wilhelmina Smith. "An empirical evidence on the usage of internet marketing in the hospitality sector in an emerging economy and its relationship to profitability." International Review of Social Sciences and Humanities 4.1 (2012): 181-197.

\section{AUTHORS PROFILE}

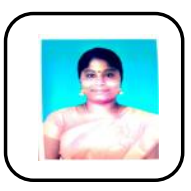

Mrs.G.Thamaraiselvi has been rendering her services as an Assistant Professor of Commerce, Kalasalingam Academy of Research and Education, krishnankoil, She published three papers in UGC listed journal and also three papers is ISBN. She acting as a lifetime member of various professional bodies like TERA,SSHRA, IEDRC and Association of North America Higher Education International. She presented many research papers in various seminar and conferences conducted national and international level. 